\title{
Chromium content in fish and rice and its effect on public health along the downstream Opak River, Bantul District, Indonesia
}

\author{
DJOKO RAHARDJO ${ }^{1, \vartheta}$, DJUMANTO ${ }^{2}$, ANIEK PRASETYANINGSIH ${ }^{1}$, BORIS LAOLI $^{1}$, \\ WINDU S. MANUSIWA ${ }^{1}$ \\ ${ }^{1}$ Faculty of Biotechnology, Universitas Kristen Duta Wacana. Jl. Dr. Wahidin Sudirohusodo No. 5-25, Yogyakarta City 55224, Yogyakarta, Indonesia. \\ Tel./fax.: +62-27-4563929, `email: 1ely4192@yahoo.com \\ ${ }^{2}$ Department of Fisheries, Faculty of Agriculture, Universitas Gadjah Mada. Jl. Flora, Bulaksumur, Sleman 55281, Yogyakarta, Indonesia
}

Manuscript received: 19 August 2021. Revision accepted: 24 November 2021.

\begin{abstract}
Rahardjo D, Djumanto, Prasetyaningsih A, Laoli B, Manusiwa WS. 2021. Chromium content in fish and rice and its effect on public health along the downstream Opak River, Bantul District, Indonesia. Intl J Bonorowo Wetlands 11: 69-74. The activities of the leather home industry are overgrowing, causing the liquid waste flowing into the river also to increase so that the threat to the river ecosystem and river water users also increases. This study aimed to determine the concentration of chromium in environmental components, agricultural commodities, fisheries, and the risk to public health. Sampling was carried out from February to August 2020 in irrigation canals and rice fields using the Opak River flow. The number of sampling locations is determined at six stations. Water, sediment, fish, and rice were collected as samples at each station. All samples were analyzed using Atomic Absorption Spectrophotometry (AAS). The results showed that chromium metal is found in solid or mineral compounds with other elements. The highest concentration was found in rice plants with an average of 1.0105-6.2870 mg/kg, followed by rice fields $(1.2062 \mathrm{mg} / \mathrm{kg})$, river sediments (0.7126), fish (0.3799-0.8489), irrigation water $(0.2393 \mathrm{mg} / \mathrm{L})$, and the lowest were found in river water $(0.0188 \mathrm{mg} / \mathrm{L})$. The Tolerable Maximum Intake of chromium in tilapia meat was $3.0271 \mathrm{~kg} /$ week and Spotted barb meat was $1.3546 \mathrm{~kg} / \mathrm{week}$. The daily intake of chromium in rice ranged from 18.475 to 28.733 (mg/kg BW/day). Hazard quotient (HQ) level of consumption of chromiumcontaminated rice ranged from 4.618-7.183. The HQ value at all research sites exceeds the safe value for health set by World Health Organization (WHO), namely $\mathrm{HQ}<1$.
\end{abstract}

Keywords: Contamination, heavy metals, home industry, Yogyakarta.

\section{INTRODUCTION}

The Governor of the Special Region of Yogyakarta, Sri Sultan Hamengku Buwono $X$, has inaugurated an integrated Industrial Estate in Srimulyo and Sitimulyo, Piyungan Sub-district, Bantul District, whose development is environmentally friendly and labor-intensive (Asmadi et al. 2009). Developing the Industrial Estate is expected to overcome welfare inequality between regions, equal distribution of the economy and employment opportunities, and move the local economy. The number of industries currently is 12 units, and 10 of them are leather industry. One of the ten leather industry units has carried out waste treatment relatively well. In contrast, the rest have not processed their waste and do not even have documents for Environmental Management Efforts and Environmental Monitoring Efforts (UKL-UPL) (Asmadi et al., 2009). This condition places the environment and society in a vulnerable position to contamination and receives health impacts from waste disposal that has not been appropriately managed.

The leather tanning industry is one type of industry that, in its production process, uses a lot of water and some chemical liquids, such as chromium (III) salts and sulfur compounds (McLaughlin et al., 2000). Based on the results of monitoring waste disposal by the Environmental Agency of Bantul District in 2015 (Asmadi et al. 2009), it is known that the waste disposal of six leather factories into the Opak River does not meet quality standards. Disposal of industrial leather waste containing heavy chromium metal can cause environmental pollution and threaten public health (Rajeshkumar and Li 2018).

Chromium contaminants are toxic, carcinogenic, bioaccumulative, and biomagnifying (Wardhana 2004; Kosnett 2007; Plaa 2007; Laibu et al. 2018; Pranoto et al. 2019). The continuous disposal of leather industry wastewater into the environment will cause the heavy metal chromium to spread to various environmental components in Banyakan village. The spread of heavy metal chromium can be through irrigation water, healthy water, sediment, soil, different types of food plants, aquatic animals, and can even accumulate in the hair and nails of villagers (Rahardjo 2014; Odongo et al. 2019). These results are corroborated by research conducted by Rahardjo (2015), that the heavy metal chromium has been distributed in almost all environmental components of Banyakan village such as water $(1.538 \mathrm{mg} / \mathrm{L})$, sediment $(68.85 \mathrm{mg} / \mathrm{kg})$, soil $(1.582$ $\mathrm{mg} / \mathrm{kg})$, shallow groundwater $(0.352 \mathrm{mg} / \mathrm{L})$, plants $(14.870$ $\mathrm{mg} / \mathrm{kg}$ ), aquatic animals (9.269 $\mathrm{mg} / \mathrm{kg}$ ). In addition, aquatics biotics found in these waters contain heavy metal chromium with varying concentrations ranging from 0.3 $12.32 \mathrm{mg} / \mathrm{kg}$, with an average of $3.76 \mathrm{mg} / \mathrm{kg}$. The chromium concentration in water, sediment, and aquatic biotics from 2014 to 2016 continued to increase (Rahardjo 
and Prasetyaningsih 2017). Accumulation of heavy metals through the food chain can affect human health (ElKammar et al., 2009).

The wider distribution, the increasing concentration on the environment, and the accumulation of various components of living organisms pose a dire threat to the diverse agricultural, fishery, and public health businesses around industrial areas. This condition is certainly counterproductive to the initial goal of developing the Piyungan Industrial Estate, which is for equity and encouraging economic growth in the Piyungan sub-district. Therefore, it is necessary to conduct a comprehensive study on the profile of chromium contamination along the Opak River and its effects on agricultural commodities, fisheries, and public health. The output of this research is expected to be used as a reference for determining recommendations by policymakers to make efforts to manage the environment better to avoid losses and public health problems.

\section{MATERIALS AND METHODS}

\section{Description of the study sites and collection of samples}

Sampling was carried out in February and August, representing the rainy and dry seasons. The number of areas sampled was six sub-districts: Piyungan, Banguntapan, Pleret, Jetis, Imogiri, and Pundong, Bantul District, Indonesia (Figure 1). Sampling stations in each sub-district are irrigation canals and rice fields that flow from the Opak River. Each sub-district has three substations for sampling river water, irrigation water, irrigation sediment, paddy soil, and rice grains.

Eight samples were taken at each station (S1-S6), namely water samples consisting of river water, irrigation water, and healthy water. Then river sediments and paddy fields, while aquatic biota consists of fish, mollusks, and plants. Water samples were taken from the channel column using a $1 \mathrm{~L}$ sample bottle, while the bottom sediment was taken using a shovel as much as $100 \mathrm{~g}$. The water sample was then added with concentrated $\mathrm{HNO}_{3}$ as a preservative by $3 \%$ by volume and cooled at $4^{\circ} \mathrm{C}$ (APHA 2001). Fish are caught with cast nets, while mollusks are collected by handpicking. The rice plants collected consisted of $10 \mathrm{~g}$ of rice roots and grains, each stored separately using a plastic bag. Samples of water, sediment, biota, and rice are then brought to the laboratory using a cool box.

\section{Chromium analysis}

Water samples were extracted by adding $10 \mathrm{~mL}$ of concentrated $\mathrm{HNO}_{3}$ to $100 \mathrm{~mL}$ of sample water. The sample water is then heated at $100^{\circ} \mathrm{C}$ until the remaining volume is $\pm 50 \mathrm{~mL}$. This procedure was repeated once with the addition of concentrated $\mathrm{HNO}_{3}$ and heating of the sample. The extracted water was then filtered using filter paper soaked with $1 \% \mathrm{HNO}_{3}$ then stored in a sample bottle.

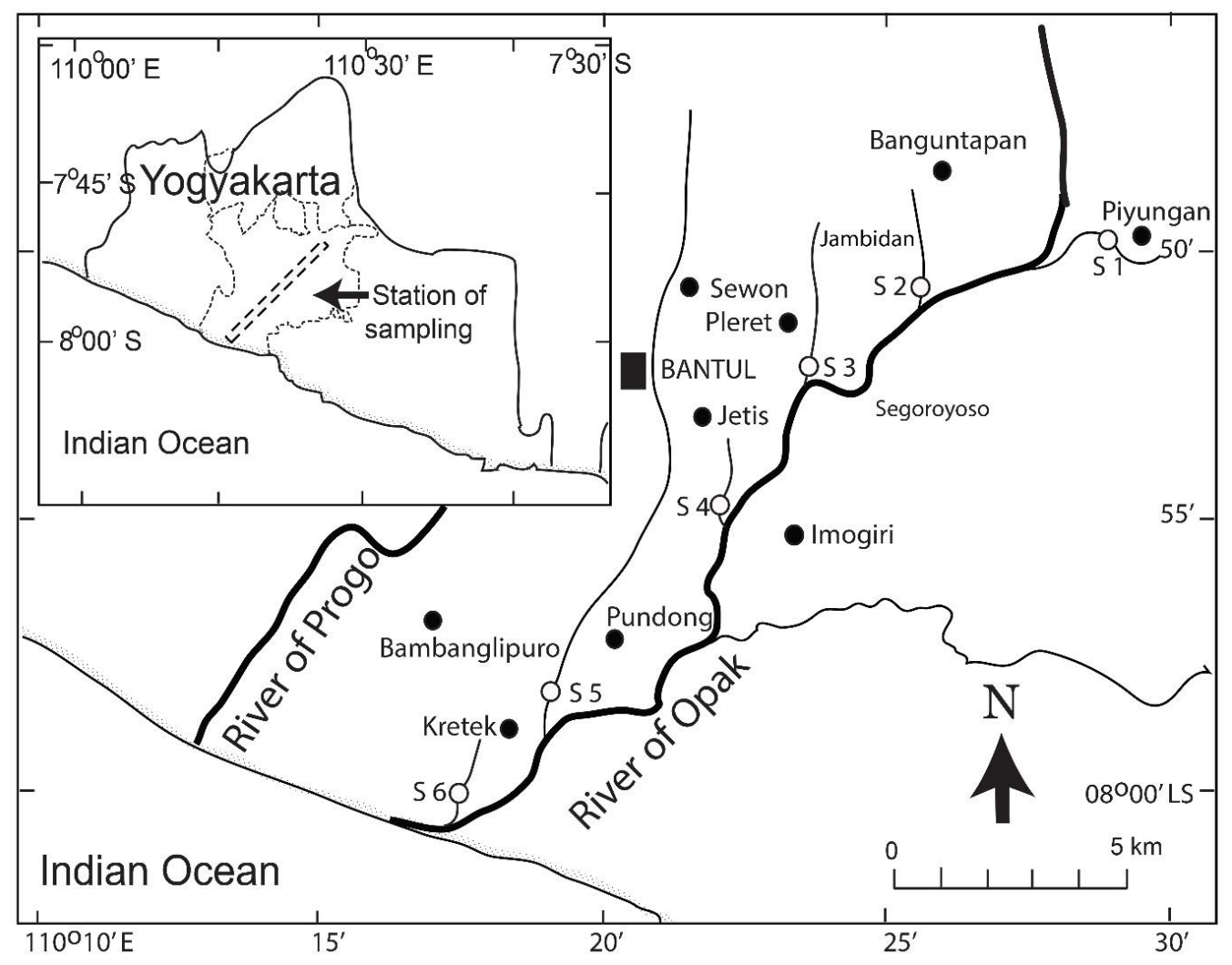

Figure 1. Determination of sampling stations in irrigation canals and rice fields in Piyungan, Banguntapan, Pleret, Jetis, Imogiri, and Pundong, Bantul District, Indonesia, received the Opak River flow. Sampling stations are indicated by open circles S1-S6. 
Soil sediment samples were extracted by the acid method (USEPA 1996). The solid sample was heated using an oven at $60^{\circ} \mathrm{C}$ until the sample was dry. Next, as much as $3 \mathrm{~g}$ of dry sample was added, $18 \mathrm{~mL}$ of $\mathrm{HCl}$ and $6 \mathrm{~mL}$ of concentrated $\mathrm{HNO}_{3}$. Then the sample is heated until the volume remains $\pm 10 \mathrm{~mL}$. The procedure was repeated once with concentrated $\mathrm{HCl}$ and $\mathrm{HNO}_{3}$ solutions added to the sample and heating. The sample was then filtered using filter paper soaked in $1 \% \mathrm{HNO}_{3}$.

Fish and mollusk samples were extracted using the acid method. Each $2 \mathrm{~g}$ was taken and put into an Erlenmeyer, and then aqua regia was added in a 1 -part $\mathrm{HNO}_{3}{ }^{+3}$ parts $\mathrm{HCl}$ ratio so that the volume was $10 \mathrm{~mL}$. The sample is heated using a stove, and this process is repeated twice. The sample extract obtained was transferred into a $10 \mathrm{~mL}$ volumetric flask. If the volume is less than $10 \mathrm{~mL}$, distilled water is added. The extract was then filtered using filter paper.

Rice plant samples consisting of roots, stems, leaves, and grains were extracted using the acid method. The rice plant was separated, washed using distilled water three times, and rinsed using deionized water. Then the sample was dried using an oven at a temperature of $65^{\circ} \mathrm{C}$. Then the sample was pulverized using a mortar and stored. Each plant sample used for extraction was $2 \mathrm{~g}$.

Chromium content in the sample extract was measured using the Atomic Absorption Spectrophotometry (AAS) method based on SNI 06-6989.17-2004 (Indonesian National Standardization Agency 2004). The analysis process was carried out with the PerkinElmer PinAAcle 900T Atomic Absorption Spectrometer.

The AAS analysis was carried out in several stages: measuring the chromium concentration, comparing it with a calibration curve, and calculating the concentration. After measurement, the data obtained is calculated to obtain the concentration of chromium in the sample using the formula:

$$
\mathrm{K}=(\mathrm{C} \times \mathrm{B}) \times \mathrm{V} / \mathrm{w}
$$

Description $\mathrm{K}$ is the concentration of $\mathrm{Cr}(\mathrm{mg} / \mathrm{kg}), \mathrm{C}$ is the concentration of the measured sample $(\mathrm{mg} / \mathrm{kg}), \mathrm{B}$ is the concentration of the blank $(\mathrm{mg} / \mathrm{kg}), \mathrm{V}$ is the final volume of extract $(10 \mathrm{ml})$ in the sample being tested, and $\mathrm{w}$ is the weight of the sample.

\section{Health risk analysis}

The formula can determine heavy metals that enter the body daily:

\section{Daily intake $=\sum(\mathrm{Ci} x \mathrm{li}) / \mathrm{BW}$}

Daily intake results from multiplying $\mathrm{C}$, the heavy metal concentration (ppm), and I, namely ingestion rate (g/day). The average I in Indonesia is $223 \mathrm{~g} /$ day. I was then divided by $\mathrm{BW}$, namely the average body weight of Indonesian adults, $60 \mathrm{~kg}$ (Heikens et al. 2005). The level of consumption risk or Hazard quotient (HQ) is the risk of consuming rice contaminated with heavy metals. HQ value $<1$ is declared safe for health and otherwise dangerous if HQ > 1. Tolerable Daily Intake (TDI) is a safe tolerance dose for daily consumption of toxic chemicals. According to World Health Organization (WHO) (1996) in Baars et al. (2001), the value of TDI in rice, the estimated long-term value of the effect of heavy metals in the body or HQ can be calculated by the formula:

$$
\text { HQ = Daily intake } / \text { TDI }
$$

\section{RESULTS AND DISCUSSION}

\section{Results}

Table 1 presents chromium concentrations in river and irrigation water, river sediments, and rice fields. In all samples observed, heavy metal chromium was found with varying concentrations. The highest chromium concentration was found in the paddy soil samples with a range of $1.0370-1.6990 \mathrm{mg} / \mathrm{kg}$ and an average of 1.2062 $\mathrm{mg} / \mathrm{kg}$, then in river sediment samples with a range of $0.0736-1.4923 \mathrm{mg} / \mathrm{L}$ and an average of $0.7126 \mathrm{mg} / \mathrm{L}$. And the concentration of chromium in irrigation water with a concentration range of $0.3000-0.1530 \mathrm{mg} / \mathrm{L}$ and an average of $0.2393 \mathrm{mg} / \mathrm{L}$. Finally, the lowest chromium concentration was found in river samples with a $0.0004-$ $0.0596 \mathrm{mg} / \mathrm{L}$ range and an average of $0.0188 \mathrm{mg} / \mathrm{L}$.

The chromium concentrations in aquatic organisms and rice are presented in Table 2. The studied samples consisted of fish and all parts of the rice plant, which showed that chromium concentrations were at various levels. The chromium concentration in tilapia varied from 0.0004 to $0.6570 \mathrm{mg} / \mathrm{kg}$, while in bony lip barb, it was $0.1780-1.4850 \mathrm{mg} / \mathrm{kg}$. The Director-General of BPOM issued a regulation Number $0375 / \mathrm{B} / \mathrm{SK} / 89$ concerning the maximum chromium concentration limit of $2.5 \mathrm{mg} / \mathrm{kg}$. The chromium concentration in fish is still lower than the standard from BPOM. However, the Food and Agriculture Organization of the United Nations (FAO) has set a 1 $\mathrm{mg} / \mathrm{kg}$ threshold. The bony lip barb fish samples at stations 2,4 and 5 have exceeded the threshold set by FAO. The average chromium content in the rice root samples was $2.416 \pm 0.657 \mathrm{mg} / \mathrm{kg}, 1.011 \pm 0.202$ in the rice stem, 1.547 \pm 0.292 in the leaves, and $6.287 \pm 0.920$ in the rice grains. The chromium concentration in rice grains is $5 \mathrm{X}$ more than in rice fields, resulting in a very high accumulation of chromium in rice grains. If the maximum limit of chromium concentration is $2.5 \mathrm{mg} / \mathrm{kg}$, then the chromium concentration in rice is $2.5 \mathrm{X}$ more than the standard allowable limit. The chromium concentration in aquatic organisms consisting of tilapia and bony lip barb is much lower than the maximum permissible standard. The chromium concentration in bony lip barbs (herbivores) is higher than tilapia (omnivores). The chromium concentration in fish and rice between sampling locations varied and did not trend. 
Table 1. The concentration of chromium (mg/L) in river water, irrigation canals, river sediments, and paddy fields between study sites

\begin{tabular}{lccccccccc}
\hline Sample type & S1 & S2 & S3 & S4 & S5 & S6 & Average & Std & Standards* \\
\hline River & 0.0596 & 0.0521 & 0.0004 & 0.0004 & 0.0004 & 0.0004 & 0.0189 & 0.029 & $0.05^{(*)}$ \\
Irrigation water & 0.153 & 0.226 & 0.215 & 0.255 & 0.287 & 0.300 & 0.2393 & 0.054 & $0.05^{(* *)}$ \\
River Sediment & 0.813 & 1.492 & 0.706 & 0.607 & 0.584 & 0.074 & 0.7126 & 0.459 & $80.0^{(* * *)}$ \\
Rice field soil & 1.699 & 1.168 & 1.037 & 1.198 & 1.071 & 1.064 & 1.2062 & 0.250 & $2.5^{(* * *)}$ \\
\hline
\end{tabular}

Note: ${ }^{(*)}$ Directorate General of Drug and Food Control 1989; ${ }^{(*)}$ Australian and New Zealand Environment and Conservation Council 2000; ${ }^{(* * *)}$ Ministry of State for Population and Environment of Indonesia, and Dalhousie University, Canada 1992

Table 2. The concentration of chromium $(\mathrm{mg} / \mathrm{kg})$ heavy metal in fish and rice plants

\begin{tabular}{lcccccccc}
\hline Sample type & S1 & S2 & S3 & S4 & S5 & S6 & Mean & Std \\
\hline Tilapia & 0.638 & 0.492 & 0.0004 & 0.657 & 0.0004 & 0.492 & 0.380 & 0.302 \\
Bonylip barb & 0.771 & 0.553 & 1.105 & 0.178 & 1.485 & 1.002 & 0.849 & 0.456 \\
root & 1.249 & 1.092 & 1.169 & 2.553 & 0.802 & 0.768 & 2.416 & 0.657 \\
stem & 1.394 & 1.058 & 0.830 & 0.944 & 0.889 & 0.948 & 1.011 & 0.202 \\
leaf & 2.032 & 1.778 & 1.395 & 1.438 & 1.318 & 1.321 & 1.547 & 0.292 \\
rice & 6.331 & 7.731 & 6.611 & 5.736 & 6.342 & 4.971 & 6.287 & 0.920 \\
\hline
\end{tabular}

The chromium concentration in rice plants consisting of roots, stems, leaves, and rice grains showed a higher concentration than chromium concentration in fish. These data indicate that fish accumulate less chromium than plants. Compared with chromium concentration in river sediments, chromium concentration in river water showed an accumulation of 37.7 times higher. Likewise, chromium concentration in the deposition of paddy soil compared to irrigation water showed a collection of 4.6X times higher. These data indicate that chromium as the heavy metal will accumulate in the sediment more. The accumulation of chromium increases as it is further away from the waste disposal center containing chromium.

Farmers were given a questionnaire to determine the amount of rice consumption. The amount of rice consumed by farmers is then used to calculate the daily intake of $\mathrm{Cr}$. The results of the questionnaire data analysis on rice farmers showed that the daily intake of $\mathrm{Cr}$ in rice ranged from 18.5 to $28.7(\mathrm{mg} / \mathrm{kg} \mathrm{BW} /$ day), so that the value of chromium intake at all locations had exceeded the quality standard of $0.023 \mathrm{mg} / \mathrm{kg} /$ day (USEPA 2011). Based on the calculation of the HQ value, which describes the level of risk of rice consumption that accumulates chromium, the results of the HQ value range from 4.618 to 7.183 . The HQ value at all study sites has exceeded the safe value for health set by WHO, namely $\mathrm{HQ}<1$. The Provisional Tolerable Weekly Intake (PTWI) value of chromium set by WHO/FAO (2004) is $23.3 \mathrm{~g} / \mathrm{kg}$. The Maximum Weekly Intake (MWI) value within one week, assuming an adult weight of $50 \mathrm{~kg}$, then the maximum value of chromium concentration in fish meat consumed is $1.15 \mathrm{mg} \mathrm{Cr} /$ week. Meanwhile, the Tolerable Maximum Intake (TMI) of chromium in tilapia meat is $3.0271 \mathrm{~kg} /$ week, and bony lip barb fish meat is $1.3546 \mathrm{~kg} /$ week.

\section{Discussion}

The leather tanning industry uses chromium for tanning. The home tanning industry in the Piyungan Industrial Estate (KIP) is suspected to be the source of the entry of chromium into the environment, especially in the downstream waters of the Opak River. KIP that disposes of liquid waste from the leather home industry into the Opak River causes the heavy metal chromium to be distributed, absorbed, and accumulated in various aquatic organisms downstream of the Opak River. The chromium concentration was found in higher amounts in paddy soil and river sediments than chromium concentration in river water and paddy field water. These results align with the research results conducted by Webera et al. (2013) and Rahardjo and Prasetyaningsih (2017) that chromium pollutants are most widely distributed in sediments than in water. It is due to the nature of chromium, which binds organic matter quickly to sediment or soil (Harahap 1991). Although chromium concentration in rice fields and river sediments is the highest, according to the Indonesian Ministry of Population and Environment and Dalhousie University, Canada (1992), the concentration is still below the critical limit of $2.5 \mathrm{ppm}$. Although chromium concentration in river and rice field sediments is still below the threshold, absorption, translocation, and bioaccumulation mechanisms can cause a high accumulation of chromium pollutants in various mollusk aquatic biota, fish, and various agricultural commodities.

Meanwhile, chromium concentration in water was found in relatively small amounts, but this amount had exceeded the specified quality standard of $0.05 \mathrm{mg} / \mathrm{L}$, especially in irrigation water. Based on the results of this study, the existence of a tannery home industry that dumps its liquid waste into the river is a potential source of chromium pollution along the downstream Opak River and along with irrigation flows and rice fields. The location 
adjacent to the liquid waste disposal source has a higher concentration of chromium pollutants than other locations.

The concentration of chromium in fish is lower than in rice because fish are actively moving or transported from one location to another in search of suitable habitats, including avoiding polluted environments and finding food sources. In addition, Aquatic organisms, such as fish, have fast movements to prevent the effects of pollution (Edward 2019). However, fish that live in closed/restricted habitats, such as ponds, reservoirs, lakes, and bays, will find it difficult to avoid the effects of pollutants. In addition, tilapia and bony lip barb feed in the form of phytoplankton or zooplankton, which has a small accumulation of heavy metals. Meanwhile, rice plants that live permanently in specific locations and continuously for about 3-4 months will contact chromium to allow higher absorption, transformation, and accumulation.

The highest accumulation of chromium concentration in rice was found in the grain, followed by leaves, roots, and lowest in the stem. The very high mobility of chromium from the rice plant roots to the plant organs can cause heavy metals in rice grains and leaves. As a non-essential metal that is highly toxic, $\mathrm{Cr}$ metal can affect the high mobility from roots to leaves and grains of plants (Yoon et al. 2006). This effect mainly occurs during photosynthesis, synthesis of antioxidant enzymes, and chlorophyll synthesis. The accumulation process occurs in cells chemically to be toxic to plants.

Meanwhile, the concentration of chromium contaminants in the roots and stems was lower than in the leaves and grains. It is caused by the chromium absorbed by the roots being directly mobilized to other organs for metabolic processes. The roots absorb heavy metals in the soil, then transported to the stem through the endodermis, and then translocated to the plant's shoots through the xylem (Irhamni et al., 2018). Xylem sap through the membrane carries heavy metals to shoots and leaves. The presence of chromium in various environmental components poses potential environmental and health risks. Through direct contact, drinking and ingesting contaminated food can pose a severe threat to human health (Al-Saleh et al. 2004; Park et al. 2004; Komárek et al. 2008; Lu et al. 2011).

The high chromium concentration in fish and rice grains and the high rice consumption pattern resulted in a high rate of chromium intake through fish and rice consumption. Based on direct interviews with several farmers, most of the harvested rice is consumed by themselves. If there is excess, it is only sold in markets closest to the residence. The HQ calculation results show that all areas have HQ values ranging from 4.618 to 7.183 , much higher than that set by $\mathrm{WHO}$, namely $\mathrm{HQ}<1$. It indicates that the community's consumption of fish and rice has an unsafe level of risk. It is necessary to conduct a risk management study by determining the safe limit of chromium concentration, amount of consumption, time, frequency, and duration of exposure. In addition, risk management programs can be more focused on technological approaches, for example, improving the production process and processing of leather industry waste, socio-economic systems, and institutional strategies for leather tanning industry artisans and the government.

To conclude, the chromium-contaminated wastewater from the leather tanning industry, discharged into the Opak River, is the main factor causing the distribution of chromium in various environmental components. The chromium is found in different ecological parts. The highest chromium concentration was found in rice grains, followed by rice fields soil, river sediments, fish, irrigation water, and the lowest river water. The TMI of chromium in tilapia and bony lip barb is much higher than the MWI set by WHO/FAO. The value of the daily intake of chromium in rice far exceeds the limit set by the USEPA (2011). The hazard quotient level of consumption of chromiumcontaminated rice at all research sites far exceeds WHO's safe value for health.

\section{ACKNOWLEDGEMENTS}

Thanks are conveyed to the Faculty of Biotechnology Universitas Kristen Duta Wacana (UKDW), Yogyakarta, Indonesia, for providing research funds, the Environment Service, the Food Crops Agriculture Service, the Bantul District Marine and Fisheries Service for providing permits and assisting researchers in coordinating the implementation research in the field. Thank are also conveyed to the Bappeda of Bantul District for allowing researchers to submit their research results and recommendations to related parties for consideration in evaluating and developing an environmentally friendly Piyungan Industrial Estate.

\section{REFERENCES}

Al-Saleh I, Shinwari N, El-Doush I, Biuedo G, Al-Amodi M, Khogali F. 2004. Comparison of mercury levels in various tissues of albino and pigmented mice treated with two different brands of mercury skinlightening creams. Biometals 17 (2): 167-175. DOI: 10.1023/B:BIOM.0000018377.17857.88.

APHA. 2001. Standard Methods for the Examination of Waste and Wastewater. 18th Edition. American Public Health AssociationAWNA-WEF, Washington DC.

Asmadi, Endro S, Oktiawan W. 2009. Chrome (Cr) reduction in leather industry waste in tannery process using alkaline compounds $\mathrm{Ca}$ $(\mathrm{OH})_{2}, \mathrm{NaOH}$, and $\mathrm{NaHCO}_{3}$ (Case study of PT. Trimulyo Kencana Mas Semarang). J Air Indonesia 5 (1): 41-54. DOI: 10.29122/jai.v5i1.2431. [Indonesia]

Baars AJ, Theelen RMC, Janssen PJCM, Hesse JM, Van Apeldoorn ME, Meijerink MCM, Verdam L, Zeilmaker MJ. 2001. Re-evaluation of human-toxicological maximum permissible risk levels. Report no 711701025. National Institute for Public Health and the Environment (RIVM), Bilthoven, Netherlands.

Edward. 2019. Accumulation of $\mathrm{Pb}, \mathrm{Cd}, \mathrm{Ni}$, and $\mathrm{Zn}$ heavy metals in fish meat in Kao Bay, Halmahera. J Fish Mar Sci 2 (2): 59-71. DOI: 10.15578/jkpt.v2i2.7970.

El-Kammar AM, Ali BH, El-Badry AM. 2009. Environmental geochemistry of River Nile bottom sediments between Aswan and Isna, Upper Egypt. Res J Appl Sci 5 (6): 585-594.

Food and Agriculture Organization [FAO]/ World Health Organization of the United Nations [WHO]. 2004. Summary of Evaluations Performed by the Joint FAO/WHO Expert Committee on Food Additives (JECFA 1956-2003). (First Through Sixty First Meetings). ILSI Press International Life Sciences Institute, Washington, DC, US. 
Harahap S. 1991. Cakung River Water Pollution Level in Terms of Physicochemical Properties, Especially Heavy Metals and Diversity of Benthos Macro Animal Species. [Thesis]. PSL-Post Graduate Program, Institut Pertanian Bogor, Bogor. [Indonesian]

Heikens A, Sumantri S, van Bergen M, Fokkert L, Widianarko B, van Leuwen K, Seinen W. 2005. The impact of the hyperacid Iijen Crater Lake Part II: A total diet study. J Environ Geochem Health 27 (1) 475- 483. DOI: $10.1007 / \mathrm{s} 10653-005-5229-3$.

Indonesia National Standardization Agency. 2004. Water and Wastewater, Part 17: Method of Total Chromium Test (Cr-T) with the Absorption Spectrophotometry Method Atom (SSA). SNI 06-6989.17-2004. [Indonesian]

Irhamni, Pandia S, Purba E, Hasan W. 2018. Kajian akumulator beberapa tumbuhan air dalam menyerap logam berat secara fitoremediasi. J Serambi Engineering 3 (2): 344-351. DOI 10.5281/ZENODO.400012. [Indonesian]

Komárek M, Chrastny V, Mihaljevic M. 2008. Lead isotopes in environmental sciences: A review. Environ Intl 34 (4): 562-577. DOI: 10.1016/j.envint.2007.10.005.

Kosnett MJ. 2007. Heavy metal intoxication and chelators. In: Katzung BG (eds). Basic and Clinical Pharmacology. 10th Ed (International Ed). Boston, Mc Graw Hill. P, New York.

Laibu PK, Maingi J, Kebira A. 2018. Determination of bacteria composition, heavy metal contamination, and physicochemical parameters of fish pond water in Abothuguchi Central, Meru County, Kenya. Bioteknologi 15 (2): 66-79. DOI: 10.13057/biofar/c150103.

Lu Y, Yin W, Huang LB, Zhang GL, Zhao YG. 2011. Assessment of bio accessibility and exposure risk of arsenic and lead in urban soils of Guangzhou City, China. Environ Geochem Health 33 (2): 93-102. DOI: $10.1007 / \mathrm{s} 10653-010-9324-8$.

McLaughlin MJ, Hamon RE, McLaren RG, Speir TW, Rogers SL. 2000 Review: A bioavailability-based rationale for controlling metal and metalloid contamination of agricultural land in Australia and New Zealand. Aust J Soil Res 38 (6): 1037-1086. DOI: 10.1071/SR99128.

Ministry of State for Population and Environment Republic of Indonesia and Dalhousie University Canada. 1992. Environmental Managemen in Indonesia. Report on Soil Quality Standards for Indonesia (interim report). Dalhousie University Canada, Canada.

Ouma KO, Otieno SA, Sharma RR 2019. Effects of selected heavy metals on morphology of Oreochromis niloticus and Clarias gariepinus along Ruiru River, Kenya. Bonorowo Wetl 9 (2): 86-101. DOI: 10.13057/bonorowo/w090204

Park RM, Bena JF, Stayner LT, Smith RJ, Gibb HJ, Lees PS. 2004 Hexavalent chromium and lung cancer in the chromate industry: A quantitative risk assessment. Risk Anal 24 (5): 1099-1108. DOI 10.1111/j.0272-4332.2004.00512.x
Plaa GL. 2007. Introduction to toxicology: Occupational and environmental. In: Katzung BG (eds). Basic and Clinical Pharmacology. 10th Ed (International Ed), Boston, Mc Graw Hill, New York.

Pranoto, Rosariastuti R, Prihandoko A. 2018. Short Communication: The utilization and effectiveness test of andisol soil-bioballAgrobacterium sp. toward heavy metal chrome removal. Biodiversitas 19 (5): 1955-1959. DOI: 10.13057/biodiv/d190547.

Rahardjo D, Prasetyaningsih A. 2017. Distribution and accumulation of chromium in the leather industrial area of Banyakan Village. Proceedings of the Third National Seminar. Malang, 29 April 2017. [Indonesian]

Rahardjo D. 2014. Profil Cemaran Krom pada Air Permukaan, Sedimen, Air Tanah dan Biota serta Akumulasi pada Rambut dan Kuku Warga Masyarakat di Sekitar Kawasan Industri Penyamakan Kulit Desa Banyakan, Sitimulyo, Piyungan Bantul. Lembaga Penelitian dan Pengabdian Masyarakat Universitas Kristen Duta Wacana, Yogyakarta. [Indonesian]

Rahardjo D. 2015. Profil Cemaran Kromium di Lingkungan serta Konsentrasi dan Akumulasinya dalam Darah dan Rambut. Laporan Penelitian. Fakultas Bioteknologi, Universitas Kristen Duta Wacana, Yogyakarta. [Indonesian]

Rajeshkumar S, Li X. 2018. Bioaccumulation of heavy metals in fish species from the Meiliang Bay, Taihu Lake, China. Toxicol Rep 5: 288-295. DOI: 10.1016/j.toxrep.2018.01.007.

United States Environmental Protection Agency (USEPA). 1996. Acid digestion of sludges, solids, and soils; USEPA 3050B. In: SW-846 Pt 1; Office 404 of Solid and Hazardous Wastes. United States Environmental Protection Agency Cincinnati, $\mathrm{OH}$

United States Environmental Protection Agency (USEPA). 2011. Exposure Factors Handbook 2011 Edition (Final Report). U.S. Environmental Protection Agency, Washington, DC, EPA/600/R09/052F, 2011. Available at: https://cfpub.epa.gov/ncea /risk/recordisplay.cfm?deid= 236252 .

Wardhana WA. 2004. Impact of Environmental Pollution. Andi Publisher, Yogyakarta. [Indonesia]

Webera P, Behr ER, Knorr CDL, Vendruscolo DS, Flores EMM, Dressler VL, Baldisserotto B. 2013. Metals in the water, sediment, and tissues of two fish species from different trophic levels in a subtropical Brazilian river. Michrochem J 106: 61-66. DOI: 10.1016/j.microc.2012.05.004.

World Health Organization (WHO). 1996. Guidelines for Drinking-Water Quality. 2nd edn, vol. 2. Health Criteria and Supporting Information, WHO, Geneva.

Yoon J, Xinde C, Qixing Z, Ma LQ. 2006. Accumulation of $\mathrm{Pb}, \mathrm{Cu}$, and $\mathrm{Zn}$ in native plants growing on a contaminated Florida site. Sci Total Environ 368 (1-2): 456-464. DOI: 10.1016/j.scitotenv.2006.01.016. 